\title{
Florida Crop/Pest Management Profile: Carambola ${ }^{1}$
}

\author{
Mark A. Mossler and Jonathan Crane ${ }^{2}$
}

\section{Production Facts}

- The Florida production of carambola (approximately 500 acres) represents over ninety percent of all carambola grown in the U.S. A small amount of the fruit is grown in Hawaii $(1,2)$.

- Based on an average yield per acre of 40,000 pounds, a price per pound of $\$ 1.50$, and a packout of 60 percent, the Florida crop is worth approximately $\$ 18$ million annually (1).

\section{Production Regions}

Carambola (Averrhoa carambola), also known as star fruit, is grown primarily in southern Florida. In 2000, 52 percent of Florida's carambola acreage was located in Miami-Dade County. The remainder of carambola acreage was located in Lee, Broward, Palm Beach, and other counties with the appropriate climate (3).

\section{Production Practices}

The carambola tree is classified as an evergreen and is in the Oxalidaceae family. It is a plant that is indigenous to India and Southeast Asia and was first introduced into Florida over a century ago. The tree is small to medium in height
(20 to 30 feet), has a spreading canopy, and is either single or multi-trunked. The majority of the fruit production occurs in the middle of the canopy. Compound leaves are alternate, with five to eleven leaflets per leaf. The fruit are star-shaped in cross section with generally five longitudinal ribs. Edible seeds encased in a gelatinous case are produced in the ribs. The star fruit berry may range from two to six inches in length, and does not produce sugar after picking. Consequently, the sweetest fruit are tree-ripened. The crop is considered mature when the color begins to "break" from green to gold between the ribs (3).

Carambola should be planted in soil with adequate drainage, although some varieties withstand flooding for brief periods. Since carambola is adapted to lowland subtropical and tropical climates, it does have a high water requirement. During seedling establishment, and from bloom through fruit development, a low-volume irrigation system should be able to provide supplemental moisture. A highvolume irrigation system ( 0.25 inch per hour) is required for protection during freezing conditions. Carambola groves should also be well sheltered from the wind (3).

Cultivars commonly used in Florida carambola production are "Arkin" and "Golden Star" and others are under

1. This document is CIR 1416 one of a series of the Horticultural Sciences Department, Florida Cooperative Extension Service, Institute of Food and Agricultural Sciences, University of Florida. Original publication date September 2002. Original authors included O. Norman Nesheim, professor, Food Science and Human Nutrition Department. This publication was revised November 2009. Reviewed July 2013. For additional Information, contact the Pesticide Information Office, University of Florida, P. O. Box 110710, Gainesville, FI 32611-0710, (352) 392-4721. Please visit the EDIS website at http:// edis.ifas.ufl.edu.

2. Mark A. Mossler, pest management information specialist, Department of Agronomy, Pesticide Information Office; and Jonathan Crane, professor, Horticultural Sciences Department, Tropical Research and Education Center, Homestead, Florida; Cooperative Extension Service, Institute of Food and Agricultural Sciences, University of Florida, Gainesville, FL 32611-0710.

The use of trade names in this publication is solely for the purpose of providing specific information. UF/IFAS does not guarantee or warranty the products named, and references to them in this publication does not signify our approval to the exclusion of other products of suitable composition. All chemicals should be used in accordance with directions on the manufacturer's label. 
evaluation. Seedlings of "Golden Star" are better adapted to the alkaline limestone soils of southern Florida than those of "Arkin." Consequently, the "Golden Star" variety is used as rootstock when bark or veneer grafting. Air-layering and tissue culture do not produce plants with well developed roots (3).

Carambola trees are planted from 15 to 20 feet apart within rows and from 20 to 25 feet between rows. Consequently, a mature stand would have about 130 trees per acre. For mature trees, removing upright limbs during late winter and then removing selected new regrowth in the early fall can maintain trees at a 10 to fifteen foot height without reducing yield potential (3).

The carambola flower is borne on panicles and is pink to lavender in color. Some cultivars require cross pollination while others produce abundant fruit when planted in solid blocks. There are two major bloom periods (April through May and September through October) in southern Florida. The concomitant harvests are from August through September and December through February. Usually there are a few fruits available throughout the year and the grove is picked from 25 to 30 times during the year. Properly cultivated trees may begin to produce fruit within ten to fourteen months after planting. Ten to forty pounds of fruit may be expected per tree during the first two to three years. This increases quickly as the trees mature, yielding 250 to 350 pounds per tree after as little as seven years (3).

Computer-aided pest management of tropical fruit has been implemented by the University of Florida, Institute of Food and Agricultural Sciences. The TFRUIT•Xpert diagnostic program has been developed to assist growers and others in determining diseases, insect pest problems and physiological disorders and is found in the Tropical Fruit CD-ROM (4).

\section{Insect/Mite Management}

\section{Insect/Mite Pests}

The principal pests on carambola in Florida are scales (Philephedra, plumose, long brown), Diaprepes weevil, and redbanded thrips. Minor and occasional pests include bugs (stink and squash) and fruit miners (3).

Scale (Philephedra tuberculosa, Morganella longispina, Coccus longulus)

Scales are plant-feeding insects which are often controlled by natural and released parasites, predators, and pathogens. In cases when the natural balance of predation has been disrupted, scale populations may increase to levels requiring treatment. Since scale insects are relatively immobile and at least one month is required for the egg to reach the adult stage, an infestation builds up slowly (in comparison to mites or aphids) and may be hard to spot. It is also important to verify that the scale insects attached to the plant are alive, as mummies accumulate on the plant over time. Economic thresholds for scale have not been determined. Most effective control is obtained when the scales are in nymphal stages, as egg and adult stages are recalcitrant to insecticide applications (5).

\section{Citrus Root Weevil (Diaprepes abbreviatus)}

Female root weevils generally oviposit eggs in clusters between two leaves on newly flushed foliage. After ten or twenty days, eggs hatch and larvae fall to the ground. The larvae begin feeding on the fibrous feeder roots. Successively larger larval instars feed on larger roots. The final larval stages (of at least eleven) proceed to the tap root and major lateral roots of the tree. Even if direct feeding does not girdle these roots, lesions provide entry to debilitating fungi such as Phytophthora. Adult weevils emerge over a three month period which may begin as early as March. Larval development time ranges from nine to 18 months, which includes an inactive pupal stage of one to three months. Dry weather delays development and emergence (6).

\section{Redbanded Thrips (Selenothrips rubrocinctus)}

The redbanded thrips is ubiquitous in its distribution throughout Florida, but it is generally found in damaging numbers from Orlando to Key West. Female redbanded thrips are slightly greater than $1 \mathrm{~mm}$ in length, and have a dark brown to black body underlain by red pigment, chiefly in the first three abdominal segments. The larvae is light yellow to orange, with the first three and last segments of the abdomen bright red. The life cycle of this thrips is about three weeks in Florida, and several generations are possible each year. Redbanded thrips prefer young foliage, which may lead to leaf drop, at times totally denuding trees. The frass and associated sooty mold from thrips feeding may give rise to fruit which is out-of-grade (7).

\section{Chemical Control}

Fifty percent of responding carambola growers surveyed reported insecticide use (8). Those survey respondents that provided insect damage estimates indicated that from 10 to 50 percent of the carambola crop would be lost to insect damage ( $n=7$, mean of 19 percent). Insecticides 
and miticides registered for use on Florida carambola in 2008 include azadirachtin, Bacillus thuringiensis, Beauveria bassiana, imidacloprid, insecticidal oil, insecticidal soap, malathion, methidathion, pyrethrin $+/$ - rotenone, pyriproxyfen, spinosad, and sulfur, while pyriproxyfen and methoprene are available for fire ant control (9).

In non-bearing carambola, bifenazate and bifenthrin are registered while pymetrozine, fenpropathrin, and hexythiazox are labeled for non-bearing nursery carambola. Hydramethylnon and fenoxycarb are available for fire ant control in non-bearing carambola.

\section{Crop Oils}

Crop oils work by smothering immobile insects such as scales, aphids, and mites. The oils are usually made up as 1.5 to 3 percent solutions which are applied thoroughly to each tree. Price varies based on amount and formulation used, but an average application cost is $\$ 6 /$ acre (10). The restricted entry interval (REI) for crop oils is 4 hours and there is no pre-harvest interval or PHI (11). Twenty percent of surveyed carambola growers in Florida applied oil to their acreage once (50 percent) or six times (50 percent) per season for an average use of 3.5 times per season (8).

\section{Methidathion}

Methidathion is an organophosphate insecticide used to manage sucking insects such as scale (5). The price of methidathion is $\$ 29$ per pound of active ingredient and the approximate cost per application is $\$ 11$ per acre $(8,10)$. There is a maximum of three applications per season and at least 30 days must elapse between applications. The PHI is 21 days and the REI is 72 hours (11). Twenty percent of surveyed carambola growers applied methidathion to their acreage once per season (8).

\section{Pyrethrin + Rotenone}

These two natural compounds both have contact and stomach activity and are used to manage sucking and chewing insects (13). The median price of the mixture is $\$ 900$ per pound of active ingredient and the approximate cost per application is $\$ 25$ per acre $(8,10)$. The PHI and REI are both 12 hours. Thirty percent of carambola growers reported the use of this mixture twice (67 percent) or six times ( 33 percent) for an average use of 3.3 times per season (8).

\section{Fenoxycarb}

Fenoxycarb is a carbamate compound used as an insect growth regulator, which causes death in the last pupal stage. The bait product is used to control ants (particularly the imported red fire ant). The price of fenoxycarb is $\$ 715$ per pound of active ingredient and the approximate cost per application is $\$ 14$ per acre $(8,10)$. Twenty percent of surveyed carambola growers in Florida applied fenoxycarb to their acreage once ( 50 percent) or twice ( 50 percent) for an average use of 1.5 times per season (8).

\section{Cultural Control}

Based on survey results of all tropical fruit growing respondents, 44 percent reported keeping records of pest problems, 50 percent adjusted applications (timing or rate) to protect beneficial insects and mites, and 52 percent alternated pesticides to reduce resistance. Sixty-two percent reported selecting the pesticide that is least toxic to beneficial insects and mites and 63 percent spot sprayed only infested plants or areas. Seventy percent reported selecting pesticides that are least toxic to the environment to make this the dominant form of cultural pest control (8).

\section{Biological Control}

Seven percent of the responding tropical fruit growers reported release of predatory wasps for control of lepidopteran pests. Additionally, 30 percent reported the use of biological-derived pesticides like B.t. (8).

\section{Weed Management}

\section{Weed Pests}

Weeds can reduce carambola yields by competing primarily for water and nutrients. Although individual weed species may vary regionally, predominant weed species in groves are grasses, sedges, and pigweeds (14).

\section{Chemical Control}

There are three herbicides labeled for use on bearing carambola. Glyphosate, carfentrazone, and pelargonic acid can be used on all carambola trees. Flumioxazin is registered for use only in non-bearing carambola groves/nurseries (9).

\section{Glyphosate}

Glyphosate is a phosphorylated amino acid herbicide used for total vegetation control. Glyphosate is applied as a directed spray so that carambola foliage is not injured. The median price of glyphosate is $\$ 10$ per pound of active ingredient and the approximate cost per application is $\$ 20$ 
per acre for annual weeds and $\$ 48$ for perennial weeds $(8,10)$. The REI for glyphosate is 4 hours and the PHI is 14 days (46). One hundred percent of surveyed carambola growers in Florida applied glyphosate either two (10 percent), four ( 80 percent), or five (10 percent) times for an average seasonal use of 3.9 times (8).

\section{Disease Management}

\section{Disease Pathogens}

Fungi and algae are responsible for the principal diseases affecting carambola production in Florida. The most recurrent and problematic diseases include anthracnose (Colletotrichum gloeosporioides/Glomerella cingulata) and decline (Pythium splendens). Algal spot (Cephaleuros virescens) may become prevalent in late summer through late winter. Other diseases that intermittently affect carambola production are sooty mold (Leptothyrium sp.) and leaf spot (Cercospora averrhoa, Corynespora cassiicola, Phomopsis sp., Gloesporium sp., Phyllosticta sp.). Leaf spotting is more common on stressed or nutritionally deficient trees and occurs on older leaves that normally abscise during the winter and early spring $(3,16)$.

\section{Anthracnose (caused by Colletotrichum gloeosporioides/ Glomerella cingulata)}

Anthracnose can occur on all parts of the carambola tree. Leaf infection starts as light green lesions that enlarge into irregular brown areas, giving the leaf a scorched appearance. Infected leaves may abscise. Infections on flower panicles appear as small brown or black spots which enlarge and often coalesce to cause the death of the flower. Small fruit are rapidly invaded by the fungus once they become infected and will rot and mummify on the tree. On nearly mature or ripe fruit, the resultant lesion is small and relatively cosmetic with a shallow area of hardened tissue (16).

\section{Decline (caused by Pythium splendens)}

This fungus has recently been identified as the cause of a general tree decline. Signs of decline include loss of tree vigor, leaf drop, and twig, shoot, and root die-back. Trees also demonstrate reduced fruit production in terms of number and size (3).

\section{Algal Spot (caused by Cephaleuros virescens)}

This alga commences colonization late in the summer and progresses through the winter months. Initially hard to visualize, green, grey-green, or rust colored leaf spots become raised and circular. Stems may develop cracks where infestation is high. The alga eventually produces "spores" - which are rust colored (16).

\section{Chemical Control}

Sixty percent of carambola growers surveyed reported fungicide use (8). Those survey respondents that provided damage estimates indicated that from 10 to 50 percent of the carambola crop would be lost to disease ( $n=6$, mean of 23 percent). Fungicides registered for use on carambola include sulfur, hydrogen dioxide, mefenoxam, Bacillus subtilis, copper, and azoxystrobin (9).

\section{Copper}

Copper has long been used as a fungicide and can be applied in multiple forms (copper hydroxide, copper sulfate, etc.). Copper is used to manage anthracnose, sooty blotch, leaf spot, and algal spot (16). The median price of copper hydroxide is $\$ 2$ per pound of active ingredient and the approximate cost per application is $\$ 10$ per acre $(9,17)$. The PHI and REI for copper hydroxide are 0 day and 24 hours, respectively (17). Sixty percent of carambola growers in Florida applied copper either once (33 percent), twice (33 percent), three times (17 percent) or four times (16 percent) per season for an average seasonal use of 2.2 times.

\section{Nematode Management}

\section{Nematode Pests}

Plant-parasitic nematodes are microscopic roundworms, found in soils, which primarily attack plant roots. General signs of nematode damage include stunting, premature wilting, leaf yellowing, root malformation, and related symptoms characteristic of nutrient deficiencies. Stunting and poor stand development tend to occur in patches throughout the field as a result of the irregular distribution of nematodes within the soil.

\section{Chemical Control}

There are no products registered for use on carambola in Florida that claim nematode suppression.

\section{Key Contacts}

Jonathan Crane is a professor of horticultural science located at the Tropical Research and Education Center in South Florida. He is responsible for research and extension duties associated with tropical fruit. Dr. Crane can be reached at: TREC, 18905 SW 280th St., PO Box 111569 , Homestead, FL 33031-3314, (305) 246-7001, jhcr@ufl.edu. 
Mark Mossler is a Doctor of Plant Medicine in the Agronomy Department's Pesticide Information Office at the University of Florida's Institute of Food and Agricultural Sciences. He is responsible for providing pest management and pesticide information to the public and governmental agencies. Dr. Mossler can be reached at UF/IFAS PIO, Box 110710, Gainesville, FL 32611, (352) 392 4721, plantdoc@ ufl.edu

\section{References}

1. Markle, G.M., Baron, J.J., and Schneider, B.A. Food and Feed Crops of the United States. 1998. Meister Publishing Company, Willoughby, $\mathrm{OH}$.

2. Personal communication with J. Crane, TREC, Homestead FL, December 2008.

3. Crane, J.H. 2007. Carambola Growing in the Florida Home Landscape. Horticultural Sciences document HS12. Florida Cooperative Extension Service, Institute of Food and Agricultural Sciences, University of Florida.

4. Tropical Fruits CD-ROM. UF/IFAS Extension Bookstore. Florida Cooperative Extension Service, Institute of Food and Agricultural Sciences, University of Florida.

5. Browning, H.W., Childers, C.C., Stansly, P.A., Pena, J., and Rogers, M.E. 2007. 2008 Florida Citrus Pest Management Guide: Soft-bodied Insects Attacking Foliage and Fruit. Entomology and Nematology department document ENY-604. Florida Cooperative Extension Service, Institute of Food and Agricultural Sciences, University of Florida.

6. McCoy, C.W., Rogers, M.E., Futch, S.H., Graham, J.H., Duncan, L.W. and Nigg, H.N. 2007. 2008 Florida Citrus Pest Management Guide: Citrus Root Weevils. Entomology and Nematology department document ENY-611. Florida Cooperative Extension Service, Institute of Food and Agricultural Sciences, University of Florida.

7. Denmark, H.A. and Wolfenbarger, D.O. 2008. Redbanded Thrips. Department of Entomology and Nematology, University of Florida, and Florida Department of Agriculture and Consumer Services, Division of Plant Industry Featured Creatures Website.
8. UF/IFAS Pesticide Information Office. 2001. Tropical Fruit Management Survey. Agronomy Department, Institute of Food and Agricultural Sciences, University of Florida.

9. Crane, J.H., and Mossler, M.A. 2006. Pesticides Registered for Tropical Fruit Crops in Florida. Horticultural Sciences document HS929. Florida Cooperative Extension Service, Institute of Food and Agricultural Sciences, University of Florida.

10. Anonymous pricing.

11. JMS Flower Farms labels, Vero Beach, FL.

12. Gowan labels, Yuma, AZ.

13. Wright Webb Corporation labels, Fort Myers, FL.

14. Knapp, J.L. 1999. Citrus Commodity: A Biologic and Economic Assessment of Pesticide Usage. USDA National Agricultural Pesticide Impact Assessment Program Report No. 1.

15. Monsanto Company labels, St. Louis, MO.

16. Simone, G. 1999. Disease Management in Carambola (Averrhoa carambola). Plant Pathology Department Document PDMG-V3-11. Florida Cooperative Extension Service, Institute of Food and Agricultural Sciences, University of Florida.

17. Dupont labels, Wilmington, DE. 